\title{
Professional profile of dentists who are members of the Family Health Strategy city of Marília, São Paulo: the challenge of interprofessional work
}

\author{
Perfil profissional de cirurgiões-dentistas integrantes da Estratégia Saúde da Família do município de \\ Marília-SP: o desafio do trabalho interprofissional
}

\author{
Mirella Gonçalves Caldeira PADULAª ${ }^{\mathrm{a}}$ Rinaldo Henrique AGUILAR-DA-SILVA ${ }^{\mathrm{a}}$
}

aFAMEMA - Faculdade de Medicina de Marília, Marília, SP, Brasil

\begin{abstract}
Resumo
Introdução: A inserção de profissionais de saúde bucal na Estratégia de Saúde da Família foi regulamentada em dezembro de 2000 pelo Ministério da Saúde. Estes profissionais são inseridos em um novo contexto que confronta sua formação tradicional de saber fragmentado e apresenta o desafio do trabalho interprofissional. Objetivo: Analisar o perfil e a prática interprofissional dos cirurgiões-dentistas que atuam na ESF no município de MaríliaSP. Material e método: Para a coleta de dados foi utilizado um questionário estruturado e a adaptação da Readiness Interprofissional Learning Scale (RIPLS), aplicados à 34 cirurgiões-dentistas que atuam na ESF do município de Marília -SP, no ano de 2012. Para análise dos dados foram utilizadas estatística descritiva e análise de variância não paramétrica Kruskal-Wallis, com pós-teste de comparações múltiplas S-N-K com nível de significância de $\mathrm{p}<0,05$. Resultado: Os cirurgiões-dentistas estão na faixa etária de 31 a 40 anos $(70,6 \%)$, são majoritariamente do gênero feminino $(82,4 \%)$ e $79,41 \%$ apresentam especialização em Saúde Coletiva e da Família. As comparações das diferenças entre as médias dos escores atribuídos nas respostas entre os profissionais com e sem pós-graduação nesta área foi estatisticamente significante na assertiva referente ao contingente de recursos humanos e o trabalho interprofissional. Conclusão: A pós-graduação em Saúde Coletiva e da Família proporciona aos cirurgiões-dentitas a reflexão sobre a integração no trabalho em equipe, o entendimento sobre o processo de trabalho interprofissional, a valorização das competências profissionais comuns e colaborativas e, desta forma minimiza os efeitos de uma equipe de saúde incompleta. Consideramos que os profissionais sem esta pós-graduação ficam restritos a sua formação tradicional e reducionista.
\end{abstract}

Descritores: Odontólogos; saúde da família; equipe de assistência ao paciente; relações interprofissionais.

\begin{abstract}
Introduction: The inclusion of oral health professionals within the Family Health Strategy was legislated in December, 2000, by the Ministery of Health. These professionals are included in a new context which challenges the traditional education of fragmented knowledge and presents the challenge of interprofessional work. Objective: To analyze the profile and the interprofessional practice of dentists working in the FHS in the city of Marília, São Paulo. Material and method: In 2012, a structured questionnaire and an adaptation of the Readiness Interprofissional Learning Scale (RIPLS), given to 34 dentists working in the FHS in the city of Marília, São Paulo, were used to collect data. Descriptive statistics and the nonparametric Kruskal-Wallis analysis of variance with SNK multiple comparisons post-test, at a significance level of $\mathrm{p}<0.05$, were used for data analysis. Result: The dentists are in the 31 to 40 year age range (70.6\%), are mostly women $(82.4 \%)$ and $79.41 \%$ hold a specialization in Public and Family Health. Comparisons of the differences of the mean scores of the responses among professionals, with and without graduate study in this area, were statistically significant in the statements regarding the amount of human resources and interprofessional work. Conclusion: Graduate study in Public and Family Health provides dentists with background on the integration of teamwork, the understanding about the process of interprofessional work, the enhancement of common and collaborative professional skills and thus minimizes the effects of an incomplete health team. It is considered that professionals without graduate study are restricted to their traditional and reductionist preparation.
\end{abstract}

Descriptors: Dentists; family health; patient care team; interprofissional relations. 


\section{INTRODUCTION}

The strengthening of Primary Care in Brazil has been a gradual process, translated into the increase in coverage of the Family Health Strategy (FHS) in all states in the country. However, the issue is not only the amount of coverage but the organizational quality of assistance and care. There is also evidence that countries whose health care systems are based on the principles of Primary Care attain better results in health with lower costs, greater user satisfaction, and greater equity ${ }^{1}$.

The National Policy for Primary Care has the expansion, qualification and consolidation of Primary Care as its strategic priority for the FHS. The strategy encourages the reorientation of the work process with greater potential for deepening the principles, guidelines and fundamentals of Primary Care, of expanding the resolution and impact on the health of the people and the community, and providing an important, cost-effective relationship ${ }^{2}$.

The creation of an oral health incentive to fund the actions and the inclusion of oral health professionals in the FHS occurred six years after the start of the strategy and was legislated by Ministerial Decree ${ }^{\circ} 1444$ on 28 December, 2000. The Ministry of Health considered the need to increase the access of Brazilian people to the promotion, prevention and recovery of oral health, improvement of the epidemiological indices of oral health of the population, and promote the reorganization of oral health in Primary Care ${ }^{3}$.

The daily work of the FHS has seen many challenges; among them is the development of interprofessional work. Interprofessional work in health, according to the approach adopted in the present work, corresponds to the process of interaction/collaboration among health professionals to produce health actions from a perspective of integrity. Health work is cooperative because, although each health professional provides a part of the care, there is an interdependence in this practice and the actions must be articulated toward the same end: care of the human being ${ }^{4}$.

The FHS aims at interprofessional work in the practices of its teams, and expects that the professionals who comprise it are firm in facing the problems of community health, organize their activities around planning for health promotion and monitoring, approach the family comprehensively and know how to work as part of a team. Integration among members of the multiprofessional team is necessary and highly important in order to provide comprehensive assistance to the patient and family, and fundamental for effective and quality care, because no profession can meet all the needs related to the health-disease process $^{5,6}$.

Therefore, there is the challenge of training a professional prepared and sensitized to meet the health needs of the population and who reflects the importance and impact of the social, economic, political and cultural dimensions of health. The preparation of professionals with emphasis on the promotion, prevention, recovery and rehabilitation of health, according to the principles and guidelines of Unified Public Health System (SUS:
Sistema Único de Saúde, the Brazilian public health system), is feasible through articulation between higher education and the health services ${ }^{7-9}$.

Unfortunately, there is a mismatch between the professional education to work in the FHS, in which most of the health service professionals have the traditional education of fragmented knowledge, generating curative care, without the participation of the individuals in their own health care and without interprofessional action ${ }^{5}$.

In the context of dental education, a significant portion of the public and private institutions maintain their curricula guided by the Flexnerian model, characterized by mechanism, individualism, specialization, surgical technique and emphasis on curative dentistry. This has generated a practice of high cost, low coverage, with little epidemiological impact and unequal access $^{10,11}$.

This is in contrast to the concept of interprofessional preparation in health. This is a style of education that is committed to the preparation of interprofessionals and is characterized by teamwork, the discussion of professional roles, the commitment to problem solving and negotiation in decision making. Interprofessional education enables the development of three skills common to all professions, specific to every professional area and group with respect to the specifics of every profession. These competencies are participative planning, the exercise of tolerance and negotiation an environment of collaborative networks ${ }^{12}$

Thus, the present study intends to analyze the interprofessional profile and practice of dentists working in the FHS in the city of Marília, São Paulo.

\section{MATERIAL AND METHOD}

This is a descriptive field study using a quantitative approach. The subjects of this study were a total of 38 dentists working in the FHS in the city of Marília, São Paulo, in March, 2012.

This study was approved by the Committee for Ethics in Research Involving Human Beings, in the Faculdade de Medicina de Marília, São Paulo (CEP/FAMEMA), under Protocol $n^{\circ}$ 1430/11.

Every participant in this study provided Free and Informed Consent (FIC), and was assured the freedom to participate, to refuse to participate, and the right to withdraw from the study at any time without suffering harm or embarrassment.

The data were collected from March to May of 2012, using a structured questionnaire divided into three parts, focusing on personal identification, professional education and professional activity.

This part used an adaptation of the Readiness Interprofissional Learning Scale (RIPLS) ${ }^{13}$ with structured questions (Q) concerning four dimensions of aspects of interprofessional work: I) Teamwork and effective collaboration with other health professionals (Q1 to Q15), II) Roles and responsibilities (Q16 to Q22), III) Responsibility for the patient (Q23 to Q29) and IV) 
Conditions for the development of interprofessional work (Q30 to Q35).

The 35 statements ranged along a 5-part Likert scale: Strongly Agree (1 SA), Agree (2 A), Neutral (3 N), Disagree (4 D) and Strongly Disagree (5 SD).

In the present study, the term "graduate study" was used generically to identify the education that dentists receive after graduation, and includes graduate study programs completed lato sensu ("in the broad sense") and stricto sensu ("in the strict sense").

The graduate study programs in Public Health, Social and Public Dentistry, Public Health and Family Health were also grouped around the unique, graduate study nomenclature Family and Public Health.

The data were entered into Microsoft Office Excel (2010) and Word (2010) files after collection, and were analyzed using the IBM $^{\circ}$ SPSS $^{\circ}$ Statistics program, version 21 (2012). The data obtained were initially analyzed using descriptive statistics. The nonparametric Kruskal-Wallis analysis of variance, with SNK multiple comparisons post-test at a significance level of $\mathrm{p}<0.05$, was used for the range of perception regarding interprofessional work.

\section{RESULT}

34 dentists agreed to participate in this study. Table 1 shows the demographic profile of these professionals relative to gender, age range and time worked in the FHS of the city.

Regarding professional education, 4 (11.8\%) of the dentists graduated from public institutions and 30 (88.2\%) from private institutions.

The year of graduation ranged from 1982 to 2008. Since the inclusion of oral health professionals in the FHS was legislated in December, 2000 by the Ministry of Health, 24 (70.6\%) professionals graduated in or before 2000 and 10 (29.4\%) after that year.

In the section that dealt with graduate study, 32 (94.1\%) professionals in this study had graduated in several areas (Table 2), enabling each subject to have provided more than one answer.
Regarding courses in the area of Public and Family Health, 26 (76.5\%) of the dentists had, and 8 (23.5\%) had not, studied.

Prior to working in the FHS in Marília, São Paulo, 50\% of the professionals had already worked in public health services. The reasons that led them to work in the FHS, enabling each subject to have provided more than one alternative, were: interest in the area (67.4\%), having a fixed salary (20.9\%), lack of options (4.7\%) and to be well paid (7\%).

The results of the range of perception regarding interprofessional work are shown in Tables 3, 4, 5 and 6. They show the responses of dentists both with and without graduate study in Family and Public Health, identified respectively in the lines by the upper and lower cells.

Statistical analysis revealed that only statement Q32, dealing with the lack of human resources preventing the development of interprofessional work in the team, shows a significant result with $\mathrm{p}<0.05$.

\section{DISCUSSION}

Although the subjects in the present study constitute a small sample of 34 professionals, this is significant because the authors consider all the dentists working in the FHS in Marília, São Paulo.

The data revealed that the dentists are mostly female and are in the 31 to 40 year age range. Interestingly, the same results are corroborated by other authors ${ }^{14,15}$ who have verified the femininization of the professions in the health job market, including the area of dentistry.

Morita et al. ${ }^{15}$ report that $57.4 \%$ of the actively enrolled dentists in the Federal Board of Dentistry (FBD: Brazilian professional and regulatory organization for all areas of dentistry) are up to 40 years old and that the profession currently has a female majority (56.3\%). This fact follows the progressive enrollment of Brazilian women in higher education, particularly since the 1980s. Most of the professionals are in the age range from 26 to 35 years old, and $57.4 \%$ are up to 40 years old.

The data relative to graduation from public and private educational institutions are in agreement with the national scenario in which, of the 203 colleges of Dentistry in Brazil, 28

Table 1. Sociodemographic profile of the dentists in the FHS of the city of Marília, São Paulo, 2012

\begin{tabular}{|c|c|c|c|c|}
\hline \multicolumn{5}{|c|}{ Gender } \\
\hline \multicolumn{3}{|c|}{ Male } & \multicolumn{2}{|c|}{ Female } \\
\hline \multicolumn{3}{|c|}{$17.6 \%$} & \multicolumn{2}{|c|}{$82.4 \%$} \\
\hline \multicolumn{5}{|c|}{ Age range } \\
\hline 20 to 30 years & \multicolumn{2}{|c|}{31 to 40 years } & 41 to 50 years & 51 to 60 years \\
\hline $11.8 \%$ & \multicolumn{2}{|c|}{$70.6 \%$} & $14.7 \%$ & $2.9 \%$ \\
\hline \multicolumn{5}{|c|}{ Time worked in the FHS } \\
\hline 01 to 03 years & 04 to 07 years & 08 to 11 years & 12 to 15 years & No Reply \\
\hline $26.5 \%$ & $32.4 \%$ & $23.5 \%$ & $11.8 \%$ & $5.9 \%$ \\
\hline
\end{tabular}


Table 2. Professional preparation - Area of graduate study concentration, Marília, São Paulo, 2012

\begin{tabular}{|c|c|c|}
\hline Study & Major Area & $\mathbf{N}$ \\
\hline \multirow{12}{*}{ Specialization } & Health Services Administration & 01 \\
\hline & Hospital Administration & 03 \\
\hline & Endodontics & 04 \\
\hline & Occupational Dentistry & 01 \\
\hline & Public Health Dentistry & 01 \\
\hline & Pediatric Dentistry & 03 \\
\hline & Orthodontics & 01 \\
\hline & Periodontics & 02 \\
\hline & Family Health & 17 \\
\hline & Public Health & 05 \\
\hline & $\begin{array}{c}\text { Public Health, including Family Health } \\
\text { Program (FHP) }\end{array}$ & 04 \\
\hline & Genetics & 01 \\
\hline Residency & Multiprofessional Family Health & 03 \\
\hline $\begin{array}{l}\text { Professional } \\
\text { Master's degree }\end{array}$ & - & 00 \\
\hline \multirow{4}{*}{$\begin{array}{c}\text { Academic } \\
\text { Master's degree }\end{array}$} & Experimental Surgery & 01 \\
\hline & Endodontics & 01 \\
\hline & $\begin{array}{l}\text { Social Dentistry and Preventive Pediat- } \\
\text { ric Dentistry }\end{array}$ & 01 \\
\hline & Periodontics & 01 \\
\hline Doctorate & - & 00 \\
\hline
\end{tabular}

are federal, 19 are state, 8 are municipal and, the vast majority, 148 are private ${ }^{16}$.

According to Morita et al. ${ }^{15}$, the Dentistry programs in Brazil have shown considerable growth, particularly in the last 30 years. In the period from 1992 to 2008, the development of the number of undergraduate programs was $132 \%$, with the fastest expansion occurring during the period from 1996 to 2002, reaching a growth of $87 \%$ of the total existing programs in the country at the beginning of that historical series.

Relative to the final year of the Dentistry program, most of the dentists were graduated prior to the inclusion of oral health professionals in the FHS context. This raises the challenge of qualifying these professionals to work in the FHS, as it is necessary to encourage continuing education and to stimulate professional qualification.

This reinforces the importance of the strategies of the Ministory of Health to strengthen the public policies by implementing programs in the area of health. Thus, the Centers for Training, Development and Continuing Education were created in 1998. In 2000, graduate study programs latu sensu in specialization courses and multiprofessional residencies in family health were implemented through financial incentives granted to universities and schools of public health of the state Departments of Health ${ }^{14}$.

According to Batista et al. ${ }^{17}$, it is extremely relevant that the professional be able to work in the SUS and in the FHS, observing the principles of universality, equity and integrity because the set of actions that results from this interaction provides health benefits to the community and improves the quality of life. Further, according to $\mathrm{Gil}^{14}$, the life experiences from the multiprofessional residencies may represent the best opportunity for the training of professionals from the perspective of the assistance model proposed by the FHS.

Thus, if on the one hand the Dentistry programs in the country grow, the same may be observed relative to graduate study programs in the area of Dentistry. Arouca et al. ${ }^{18}$ ascertained that the specialized workforce is concentrated in cities with populations of 100,000 inhabitants $(82.6 \%)$, with a per capita Gross Domestic Product (PC-GDP) greater than 10,000 reais (78.4\%), with a high or very high HDI-M (62.9\%) and Gini coefficient greater than $0.5(97.4 \%)$.

Interestingly, $76.47 \%$ of the professionals have specialization in Public and Family Health. These data are above the state percentage because, according to the $\mathrm{FBD}^{19}$, of the 78,082 professionals registered in the state of São Paulo, 74.51\% have some specialization with only $0.85 \%$ in Public Health Dentistry and $1.08 \%$ in Public and Family Health. However, these data may be underestimated because, in this area, the record of specialization does not involve limitations on professional practice.

Regarding the presence of dentists in the FHS, a low turnover rate is found which may support the formation of connections, the strengthening of interprofessional work, the development of guidelines and new professional practices that contribute to the strengthening of oral health in Primary Care.

According to Morita et al. ${ }^{15}$, one third of the professionals in the country have connections to public service. This scenario reveals a new professional stance in dentistry, due to some factors such as: the inclusion of oral health professionals in FHS teams; the implementation of the National Oral Health Policy, Smiling Brazil; and, the creation of Specialized Dental Centers (SDC).

Some aspects stand out relative to the range of perception regarding interprofessional work, initially over the issue "Teamwork and effective collaboration with other health professionals".

The proposal for teamwork, according to Peduzzi ${ }^{20}$, has been disseminated as a strategy for dealing with the intense process of specialization in the health area, where this process tends to deepen vertically the knowledge and intervention in individualized aspects of the health needs without concomitantly considering the coordination of actions and knowledge.

The FHS highlights teamwork as an assumed and operational guideline for the reorganization of the work process in health guided by comprehensive patient care, with the inclusion of several professional categories that may contribute to the construction of knowledge and practices that impact the multiple dimensions of health ${ }^{21,22}$. 
Table 3. Teamwork and effective collaboration with other health professionals, Marília, São Paulo, 2012

\begin{tabular}{|c|c|c|c|c|c|c|}
\hline \multicolumn{7}{|c|}{ TEAMWORK AND EFFECTIVE COLLABORATION WITH OTHER HEALTH PROFESSIONALS } \\
\hline \multirow[b]{2}{*}{ QUESTIONS } & \multirow[b]{2}{*}{$\begin{array}{l}\text { GRADUATE } \\
\text { DEGREE }\end{array}$} & \multicolumn{5}{|c|}{ ALTERNATIVES (\%) } \\
\hline & & $\begin{array}{c}1 \\
(\mathrm{SA})\end{array}$ & $\begin{array}{c}2 \\
(\mathrm{~A})\end{array}$ & $\begin{array}{c}3 \\
(\mathrm{~N})\end{array}$ & $\begin{array}{c}4 \\
(\mathrm{D})\end{array}$ & $\begin{array}{c}5 \\
(\mathrm{SD})\end{array}$ \\
\hline \multirow{2}{*}{$\begin{array}{l}\text { Q1 - Teamwork with other professionals helps me to become an } \\
\text { effective member of the health care team. }\end{array}$} & WITH & 76.9 & 23.1 & - & - & - \\
\hline & WITHOUT & 87.5 & 12.5 & - & - & - \\
\hline \multirow{2}{*}{ Q2 - For teamwork, the professionals need trust and respect for each other. } & WITH & 92.3 & 7.7 & - & - & - \\
\hline & WITHOUT & 87.5 & 12.5 & - & - & - \\
\hline \multirow{2}{*}{$\begin{array}{l}\text { Q3 - In teamwork, skills are essential for all the professionals } \\
\text { to be able to contribute to health care. }\end{array}$} & WITH & 61.5 & 26.9 & 11.5 & - & - \\
\hline & WITHOUT & 50 & 50 & - & - & - \\
\hline \multirow{2}{*}{ Q4 - Teamwork helps me to understand my own limitations. } & WITH & 38.5 & 42.3 & 11.5 & 3.8 & 3.8 \\
\hline & WITHOUT & 12.5 & 75 & - & 12.5 & - \\
\hline \multirow{2}{*}{$\begin{array}{l}\text { Q5 - The patients end up with the health benefits when the professionals } \\
\text { work together to solve problems. }\end{array}$} & WITH & 80.8 & 19.2 & - & - & - \\
\hline & WITHOUT & 100 & - & - & - & - \\
\hline \multirow{2}{*}{$\begin{array}{c}\text { Q6 - Interprofessional teamwork increases my willingness and ability to } \\
\text { understand health care and clinical problems. }\end{array}$} & WITH & 69.2 & 26.9 & 3.8 & - & - \\
\hline & WITHOUT & 37.5 & 37.5 & 12.5 & 12.5 & - \\
\hline \multirow{2}{*}{$\begin{array}{l}\text { Q7 - Interprofessional teamwork improves relationships } \\
\text { during the professional lifetime. }\end{array}$} & WITH & 53.8 & 38.5 & 7.7 & - & - \\
\hline & WITHOUT & 37.5 & 50 & 12.5 & - & - \\
\hline \multirow{2}{*}{$\begin{array}{l}\text { Q8 - Communication and skills must be learned together } \\
\text { with other health professionals. }\end{array}$} & WITH & 26.9 & 38.5 & 30.8 & 3.8 & - \\
\hline & WITHOUT & 50 & 12.5 & 25 & 12.5 & - \\
\hline \multirow{2}{*}{$\begin{array}{l}\text { Q9 - Teamwork helps me communicate better with both } \\
\text { patients and professionals. }\end{array}$} & WITH & 38.5 & 53.8 & 7.7 & - & - \\
\hline & WITHOUT & 25 & 50 & 25 & - & - \\
\hline \multirow{2}{*}{$\begin{array}{l}\text { Q10 - Teamwork helps me communicate better with patients and other profes- } \\
\text { sionals. }\end{array}$} & WITH & 38.5 & 53.8 & 7.7 & - & - \\
\hline & WITHOUT & 25 & 50 & 25 & - & - \\
\hline \multirow{2}{*}{$\begin{array}{l}\text { Q11 - It is good to have the opportunity to work in } \\
\text { a team with other health professionals. }\end{array}$} & WITH & 61.5 & 38.5 & - & - & - \\
\hline & WITHOUT & 87.5 & 12.5 & - & - & - \\
\hline \multirow{2}{*}{$\begin{array}{l}\text { Q12 - Interprofessional teamwork contributes to clarify the } \\
\text { nature of the problems of patients. }\end{array}$} & WITH & 76.9 & 23.1 & - & - & - \\
\hline & WITHOUT & 75 & 25 & - & - & - \\
\hline \multirow{2}{*}{$\begin{array}{l}\text { Q13 - My professional, graduate study education helped to } \\
\text { make me better at teamwork. }\end{array}$} & WITH & 61.5 & 15.4 & 11.5 & 7.7 & 3.8 \\
\hline & WITHOUT & 37.5 & 12.5 & 25 & 12.5 & 12.5 \\
\hline \multirow{2}{*}{ Q14 - I don't want to waste my time learning with other health professionals. } & WITH & - & - & - & 3.8 & 96.2 \\
\hline & WITHOUT & - & - & - & - & 100 \\
\hline \multirow{2}{*}{$\begin{array}{l}\text { Q15 - There is no benefit for dentists to work together } \\
\text { with other health professionals. }\end{array}$} & WITH & - & - & - & 7.7 & 92.3 \\
\hline & WITHOUT & - & - & - & - & 100 \\
\hline
\end{tabular}

The statement alluding to graduate study contributing to the professional training of the dentist for teamwork (Q13) was positive, showing a better understanding and acceptance of the FHS proposal. Lonch-Neckel et al. ${ }^{23}$ reinforce that residencies and multiprofessional specializations in Family Health allow the professional to experience multiprofessional teamwork, interdisciplinarity and the capacity to change the assistance model, thus contributing to the improvement of health assistance in Brazil.

Relative to the "Roles and responsibilities", it stands out that teamwork in the FHS context, according to Araújo, Rocha ${ }^{24}$, shows the division of responsibilities for care among the members of 
Table 4. Roles and responsibilities, Marília, São Paulo, 2012

\begin{tabular}{|c|c|c|c|c|c|c|}
\hline \multicolumn{7}{|c|}{ ROLES AND RESPONSIBILITIES } \\
\hline \multirow[b]{2}{*}{ QUESTIONS } & \multirow{2}{*}{$\begin{array}{l}\text { GRADUATE } \\
\text { DEGREE }\end{array}$} & \multicolumn{5}{|c|}{ ALTERNATIVES (\%) } \\
\hline & & $\begin{array}{c}1 \\
(\mathrm{SA})\end{array}$ & $\begin{array}{c}2 \\
(\mathrm{~A})\end{array}$ & $\begin{array}{c}3 \\
(\mathrm{~N})\end{array}$ & $\begin{array}{c}4 \\
(\mathrm{D})\end{array}$ & $\begin{array}{c}5 \\
(\mathrm{SD})\end{array}$ \\
\hline \multirow{2}{*}{$\begin{array}{l}\text { Q16 - The function of non-medical health professionals essentially } \\
\text { involves providing support for the doctors. }\end{array}$} & WITH & - & 3.8 & - & 19.2 & 76.9 \\
\hline & WITHOUT & 12.5 & - & - & 12.6 & 75 \\
\hline \multirow{2}{*}{$\begin{array}{l}\text { Q17 - There is little overlap between my functions and those } \\
\text { of other health professionals. }\end{array}$} & WITH & - & 7.7 & 7.7 & 61.5 & 23.1 \\
\hline & WITHOUT & - & 12.5 & 37.5 & 37.5 & 12.5 \\
\hline \multirow{2}{*}{$\begin{array}{l}\text { Q18 - I would feel uncomfortable if another health professional } \\
\text { knew more than I about a particular topic. }\end{array}$} & WITH & - & - & - & 23.1 & 76.9 \\
\hline & WITHOUT & - & - & - & 50 & 50 \\
\hline \multirow{2}{*}{$\begin{array}{l}\text { Q19 - I must acquire much more skill and knowledge than other } \\
\text { health professionals. }\end{array}$} & WITH & - & - & - & 53.8 & 46.2 \\
\hline & WITHOUT & - & 12.5 & - & 75 & 12.5 \\
\hline \multirow{2}{*}{ Q20 - I am not sure what my professional role is in the Family Health team. } & WITH & - & - & 3.8 & 11.5 & 84.6 \\
\hline & WITHOUT & - & 12.5 & - & - & 87.5 \\
\hline \multirow{2}{*}{$\begin{array}{l}\text { Q21 - I am able to use my own judgement in the development } \\
\text { of my activities (professional freedom) in my profession. }\end{array}$} & WITH & 30.8 & 57.7 & 11.5 & - & - \\
\hline & WITHOUT & 50 & 50 & - & - & - \\
\hline \multirow{2}{*}{$\begin{array}{l}\text { Q22 - Articulation of knowledge by means of communicative } \\
\text { and horizontal interaction is essential in teamwork. }\end{array}$} & WITH & 88.5 & 11.5 & - & - & - \\
\hline & WITHOUT & 50 & 50 & - & - & - \\
\hline
\end{tabular}

Table 5. Responsibility for the patient, Marília, São Paulo, 2012

\begin{tabular}{|c|c|c|c|c|c|c|}
\hline \multicolumn{7}{|c|}{ RESPONSIBILITY FOR THE PATIENT } \\
\hline \multirow[b]{2}{*}{ QUESTIONS } & \multirow{2}{*}{$\begin{array}{l}\text { GRADUATE } \\
\text { DEGREE }\end{array}$} & \multicolumn{5}{|c|}{ ALTERNATIVES (\%) } \\
\hline & & $\begin{array}{c}1 \\
(\mathrm{SA})\end{array}$ & $\begin{array}{c}2 \\
(\mathrm{~A})\end{array}$ & $\begin{array}{c}3 \\
(\mathrm{~N})\end{array}$ & $\begin{array}{c}4 \\
\text { (D) }\end{array}$ & $\begin{array}{c}5 \\
(\mathrm{SD})\end{array}$ \\
\hline \multirow{2}{*}{$\begin{array}{l}\text { Q23 - Making a diagnosis is the primary function } \\
\text { of the Family Health team. }\end{array}$} & WITH & 3.8 & 15.4 & 11.5 & 53.8 & 15.4 \\
\hline & WITHOUT & - & 37.5 & - & 50 & 12.5 \\
\hline \multirow{2}{*}{ Q24 - My primary responsibility in the health team is to treat the patient. } & WITH & 3.8 & 19.2 & 7.7 & 61.5 & 7.7 \\
\hline & WITHOUT & - & 25 & 12.5 & 62.5 & - \\
\hline \multirow{2}{*}{$\begin{array}{l}\text { Q25 - The team must put itself in the place of the patient in } \\
\text { order to understand the problem. }\end{array}$} & WITH & 23.1 & 57.7 & 7.7 & 11.5 & - \\
\hline & WITHOUT & 25 & 50 & 12.5 & 12.5 & - \\
\hline \multirow{2}{*}{ Q26 - The establishment of patient trust is important for teamwork. } & WITH & 46.2 & 50 & 3.8 & - & - \\
\hline & WITHOUT & 62.5 & 25 & 12.5 & - & - \\
\hline \multirow{2}{*}{$\begin{array}{l}\text { Q27 - The team should try to communicate showing } \\
\text { interest for the patients. }\end{array}$} & WITH & 61.5 & 34.6 & 3.8 & - & - \\
\hline & WITHOUT & 50 & 50 & - & - & - \\
\hline \multirow{2}{*}{$\begin{array}{l}\text { Q28 - It is important to think of the patient as a person, } \\
\text { for dental treatment. }\end{array}$} & WITH & 69.2 & 26.9 & 3.8 & - & - \\
\hline & WITHOUT & 62.5 & 37.5 & - & - & - \\
\hline \multirow{2}{*}{$\begin{array}{l}\text { Q29 - It is important that there be interaction skills and } \\
\text { cooperation with the patients, in dentistry. }\end{array}$} & WITH & 57.7 & 42.3 & - & - & - \\
\hline & WITHOUT & 62.5 & 37.5 & - & - & - \\
\hline
\end{tabular}


Table 6. Conditions for the development of interprofessional work, Marília, São Paulo, 2012

\begin{tabular}{|c|c|c|c|c|c|c|}
\hline \multicolumn{7}{|c|}{ CONDITIONS FOR THE DEVELOPMENT OF INTERPROFESSIONAL WORK } \\
\hline \multirow[b]{2}{*}{ QUESTIONS } & \multirow{2}{*}{$\begin{array}{l}\text { GRADUATE } \\
\text { DEGREE }\end{array}$} & \multicolumn{5}{|c|}{ ALTERNATIVES (\%) } \\
\hline & & $\begin{array}{c}1 \\
(\mathrm{SA})\end{array}$ & $\begin{array}{c}2 \\
(\mathrm{~A})\end{array}$ & $\begin{array}{c}3 \\
(\mathrm{~N})\end{array}$ & $\begin{array}{c}4 \\
(\mathrm{D})\end{array}$ & $\begin{array}{c}5 \\
(\mathrm{SD})\end{array}$ \\
\hline \multirow{2}{*}{$\begin{array}{l}\text { Q30 - The physical structure of the health unit does not } \\
\text { allow interprofessional teamwork. }\end{array}$} & WITH & 7.7 & 7.7 & 15.4 & 50 & 19.2 \\
\hline & WITHOUT & 25 & - & 12.5 & 50 & 12.5 \\
\hline \multirow{2}{*}{$\begin{array}{l}\text { Q31 - The number of patients that I treat daily makes contact } \\
\text { with the other members of my team impossible. }\end{array}$} & WITH & - & 15.4 & 19.2 & 57.7 & 7.7 \\
\hline & WITHOUT & 12.5 & 12.5 & 37.5 & 37.5 & - \\
\hline \multirow{2}{*}{$\begin{array}{l}\text { Q32 - The lack of human resources prevents the development } \\
\text { of interprofessional work. }\end{array}$} & WITH & 7.7 & 15.4 & 19.2 & 50 & 7.7 \\
\hline & WITHOUT & 37.5 & 37.5 & - & 25 & - \\
\hline \multirow{2}{*}{$\begin{array}{l}\text { Q33 - Access to the health unit facilitates the development } \\
\text { of interprofessional activities. }\end{array}$} & WITH & 19.2 & 57.7 & 19.2 & - & 3.8 \\
\hline & WITHOUT & - & 62.5 & 12.5 & 25 & - \\
\hline \multirow{2}{*}{$\begin{array}{l}\text { Q34 - I have a good relationship with the other members of my } \\
\text { team, which facilitates interprofessional work. }\end{array}$} & WITH & 50 & 46.2 & - & 3.8 & - \\
\hline & WITHOUT & 62.5 & 37.5 & - & - & - \\
\hline \multirow{2}{*}{$\begin{array}{l}\text { Q35 - The exceptionally large population in the Family Health Unit } \\
\text { (FHU) area of coverage complicates the work process and planning } \\
\text { actions of the health team. }\end{array}$} & WITH & 30.8 & 34.6 & 19.2 & 11.5 & 3.8 \\
\hline & WITHOUT & 37.5 & 50 & - & 12.5 & - \\
\hline
\end{tabular}

the team, where everyone participates with their specializations, contributing to the quality of providing health actions and a broad and resolute approach to care.

From this perspective, the responsibility for care becomes decentralized from the image of the physician and is shared by all the members of the team. Attention is called to Law $n^{\circ} 12.842$, from 10 July, 2013, known as the Medical Act, which regulates the practice of medicine and generated controversy by limiting the area of practice of other health professionals ${ }^{25}$.

The question about the overlap among the functions of the dentist and other health professionals (Q17) shows that the work of the dentist is rarely part of practices shared with other areas. They carry out their actions in an autonomous, independent and individualized manner and teamwork is a challenge because is brings into conflict the values, places and powers consolidated by the practices of previous models ${ }^{22}$.

Health needs have multiple dimensions that involve complex knowledge. Thus, health actions may not be performed by the isolated action of a single professional, but by the actions of different specialized professionals. Sometimes they will be in the same professional area, sometimes they will be in the interprofessional relationship. However, comprehensive care is not possible simply because of the placement of human resources from different professional areas in the same workplace, performing isolated and juxtaposed actions, executed side-byside, without coordination and without communication ${ }^{26}$.

Araújo, Rocha ${ }^{24}$ claim that a comprehensive approach among the individuals who provide the care is necessary for the development of health actions, from the perspective of integrity. It is necessary to develop a teamwork modality that provides another form of connecting the different actions and the distinct health professionals.

Thus, the establishment of a dialogic relationship in the health units, according to Mishima et al. ${ }^{27}$, may help to overcome the hierarchical relationships in which the professionals rarely know the potential of others, thereby reproducing the social division of work and establishing relationships of command and authority.

Relative to the "Responsibility towards the patient", it is reinforced that the responsibilities of the professionals included in the ESF are quite broad and aim to provide comprehensive care to families, identify health problems, encourage community action, as well as stimulate and develop social participation and control $^{2}$.

Cericato et al. ${ }^{28}$ stress that the FHS approach to the dentist's work goes far beyond clinic work because it is logical to think of health in a broad and comprehensive way.

Resolution $n^{\circ} 2.488$, dated 21 October, 2011, recommends that oral health professionals be connected to a Family Health Team and share the management and the work process of the team that is responsible for the health of the population and territory, and have common and specific tasks for the Primary Care teams ${ }^{2}$.

In this context, $61.5 \%$ of the professionals with, and $62.5 \%$ without, graduate study disagreed that the primary responsibility of the health team is to treat the patient (Q24). This shows the gradual understanding of these professionals about the various dimensions of the health-disease process and of the need for comprehensive and participatory care.

Regarding the "Conditions for the development of interprofessional work", it was found that the FHU infrastructure, 
the number of human resources in the health teams and the number of people belonging to the enrolled population interfere with the development of interprofessional work.

Vilarinho et al. ${ }^{29}$ report that the existence of a large, repressed demand and accumulated necessities hinder the total replacement of the traditional model with one of dental care that is centered on the principles and organizational guidelines of SUS.

The number of persons per team must be considered according to the degree of vulnerability of the families in the territory, where the greater the degree of vulnerability, the fewer must be the number of people treated by the team ${ }^{2}$.

Finally, the authors emphasize that comparisions of the differences between the professionals with and without graduate study in Public and Family Health, among the scores found for the responses to the statement regarding the number of human resources and interprofessional work (Q32), were statistically significant as analyzed by the nonparametric Kruskal-Wallis analysis of variance with SNK multiple comparisons post-test at a significance level of $\mathrm{p}<0.05$.

Lonch-Neckel et al. ${ }^{23}$ reported the integrity of the care and the composition of the smallest FHS teams, they identified that the lack of other professionals generates overloads and hinders the work of the health unit and that the professionals end up developing activities that exceed the limits of their skills.

Thus, despite the lack of human resources interfering with the work process in the FHS, the authors evaluate the dentists with graduate study in Public and Family Health as attentive to the qualifications of the professionals on their teams in performing and contributing to interprofessional work. In the work process, therefore, these professionals consider the number of members on their health team, but particularly their quality.

Therefore, the authors consider that the professionals with graduate study disagreed (50\%) and strongly disagreed (7.7\%) that the lack of human resources hinders the team from developing interprofessional work, because their professional education enabled understanding of the importance of the integration of actions, the interaction of agents working on health, and the enhancement of common and collaborative professional skills.

\section{CONCLUSION}

The authors consider the questionnaire used in the present work to be powerful for verifying sociodemographic characteristics and the perception of the dentists about interprofessional work. Nevertheless, relative to the evaluation of professional preparation, it is possible to infer about the quest for timeliness but not about the effectiveness of graduate study programs vis-à-vis the development of interprofessional work, which requires touching on other aspects.

From the analysis of results of the scale used in the present study, it is observed that the professionals having graduate study in Public and Family Health show a positive tendency regarding the perception of interprofessional work.

Thus, the authors consider that graduate study in Public and Family Health provides the professionals with reflection on the integration of teamwork, understanding about the process of interprofessional work, and enhancement of common and collaborative professional skills. In this way, it minimizes the effects of an incomplete health team. The authors consider that the professionals without this graduate study are limited to their traditional and reductionist preparation.

The authors thus appreciate that the process of involving oral health professional in the FHS presents the challenge of preparing dentists capable of developing interprofessional work in this context. Integration among the multiprofessional team members is necessary and highly important for providing full, effective and quality care for the patient and family. The authors consider that this perspective of transformation will be made possible through changes in the curricular guidelines of programs in the health area, by means of managers and professionals sensitive and committed to the strengthening of the integration of teaching and service, and investments in continuing education.

\section{REFERENCES}

1. Mendonça CS. Saúde da família, agora mais do que nunca! Ciênc Saúde Colet. 2009;14 (Supl 1):1493-7.

2. Brasil. Ministério da Saúde. Portaria no 2.488, de 21 de outubro de 2011. Aprova a Política Nacional de Atenção Básica, estabelecendo a revisão de diretrizes e normas para a organização da Atenção Básica, para a Estratégia Saúde da Família (ESF) e o Programa de Agentes Comunitários de Saúde (PACS). Diário Oficial da União, Brasília (DF); 24 out 2011. Seção 1:48.

3. Brasil. Ministério da Saúde. Portaria no 1.444, de 28 de dezembro de 2000. Estabelece incentivo financeiro para a reorganização da atenção prestada nos municípios por meio do Programa de Saúde da Família. Diário Oficial da União, Brasília (DF); 29 dez 2000. Seção 1:85.

4. Pirolo SM. Atuação interprofissional na terapia intensiva: a integralidade do cuidado e o agir comunicativo de Habermas [tese]. Ribeirão Preto: Escola de Enfermagem da USP; 2008.

5. Benito GAV, Silva LL, Meirelles SBC, Felippetto S. Interdisciplinaridade no cuidado às famílias: repensando a prática em saúde. Fam Saúde Desenv. 2003;5(1):66-72.

6. Oliveira EM, Spiri WC. Programa Saúde da Família: a experiência de equipe multiprofissional. Rev Saúde Pública. 2006;40(4):727-33. http://dx.doi.org/10.1590/S0034-89102006000500025

7. Gontijo LPT, Almeida, MCP, Gomide LRS, Barra RP. A saúde bucal coletiva na visão do estudante de odontologia - análise de uma experiência. Ciênc Saúde Colet. 2009;14(4):1277-85. http://dx.doi.org/10.1590/S1413-81232009000400034 
8. Faccin D, Sebold R, Carcereri DL. O processo de trabalho em saúde bucal: em busca de diferentes olhares para compreender e transformar a realidade. Ciênc Saúde Colet. 2010;15(Supl 1):1643-52.

9. Matos PES, Tomita, NE. A inserção da saúde bucal no Programa Saúde da Família: da universidade aos pólos de capacitação. Cad Saúde Pública. 2004;20(6):1538-44. http://dx.doi.org/10.1590/S0102-311X2004000600011

10. Moysés SJ. Políticas de saúde e formação de recursos humanos em odontologia. Rev ABENO. 2004;4:30-37.

11. Petrônio JLM, Macedo CLSV, Medeiros KR, Silva SF, Cabral APS, Pimentel FC, Monteiro IS. Perfil do cirurgião-dentista inserido na Estratégia de Saúde da Família em municípios do estado de Pernambuco, Brasil. Ciênc Saúde Colet. 2010;15 (Supl 2):3243-8.

12. Batista NA. Educação interprofissional em saúde: concepções e práticas. Cad FNEPAS. 2012;2:25-8.

13. Parsell G, Bligh J. The development of a questionnaire to assess the readiness of health care students for interprofissional learning (RIPLS). Med Educ. 1999;33:95-100. http://dx.doi.org/10.1046/j.1365-2923.1999.00298.x

14. Gil CRR. Formação de recursos humanos em saúde da família: paradoxos e perspectivas. Cad Saúde Pública. 2005;21(2):490-8. http:// dx.doi.org/10.1590/S0102-311X2005000200015

15. Morita MC, Haddad AE, Araújo ME. Perfil atual e tendências do cirurgião-dentista brasileiro. Maringá: Dental Press Internacional; 2010.

16. Conselho Federal de Odontologia - CFO. Faculdades de odontologia existentes no Brasil - ano 2012 [Internet] [citado em 2013 Jan 10]. Disponível em: http://cfo.org.br/wp-content/uploads/2009/10/quadro_estatistico_faculdade.pdf

17. Batista MJ, Gibilini C, Kobayashi HM, Ferreira LL, Gonçalo CS, Sousa MLR. Relato de experiência da interação entre universidade, comunidade e Unidade de Saúde da Família em Piracicaba, SP, Brasil. Arq Odontol. 2010;46(3):144-51.

18. Arouca R, Pereira HC, Alves LC. Censo demográfico da força de trabalho nas especialidades odontológicas: Brasil, 2010, volume I [Internet]. Rio de Janeiro (RJ): ENSP/FIOCRUZ: CFO, 2010 [citado em 2013 Maio 23]. Disponível em: http://www6.ensp.fiocruz.br/ repositorio/sites/default/files/arquivos/CensoDemografico.pdf

19. Conselho Federal de Odontologia - CFO. Serviços \& Consultas. Dados estatísticos [Internet] [citado em 2013 Jan 10]. Disponível em: http://cfo.org.br/servicos-e-consultas/dados-estatisticos/

20. Peduzzi M. Equipe multiprofissional de saúde: conceito e tipologia. Rev Saúde Pública. 2001;35(1):103-9. http://dx.doi.org/10.1590/ S0034-89102001000100016

21. Peduzzi M. Trabalho em equipe. Dicionário da Educação Profissional em Saúde [Internet] [citado em 2012 Jul 02]. Disponível em: http:// www.epsjv.fiocruz.br/upload/d/Trabalho_em_Equipe_ts.pdf

22. Teixeira MCB. A dimensão cuidadora do trabalho de equipe em saúde e sua contribuição para a odontologia. Ciênc Saúde Colet. 2006;11(1):45-51. http://dx.doi.org/10.1590/S1413-81232006000100011

23. Lonch-Neckel G, Seemann G, Eidt HB, Rabuske MM, Crepaldi MA. Desafios para a ação interdisciplinar na atenção básica: implicações relativas à composição das equipes de saúde da família. Ciênc Saúde Colet. 2009;14(Supl 1):1463-72.

24. Araújo MBS, Rocha PM. Trabalho em equipe: desafio para a consolidação da estratégia de saúde da família. Ciênc Saúde Colet. 2007;12(2):455-64. http://dx.doi.org/10.1590/S1413-81232007000200022

25. Brasil. Lei no 12.842 de 10 de julho de 2013. Dispõe sobre o exercício da medicina. Diário Oficial da União, Brasília (DF); 11 jul 2013; Seção 1:132.

26. Schraiber LB, Peduzzi M, Sala A, Nemes MIB, Castanhera ERL, Kon R. Planejamento, gestão e avaliação em saúde: identificando problemas. Ciênc Saúde Colet. 1999;4(2):221-42. http://dx.doi.org/10.1590/S1413-81231999000200002

27. Mishima S, Villa TCS, Silva E, Pinto IC, Almeida MCP. O velho trabalho em equipe pode ganhar cara nova? Uma perspectiva do trabalho gerencial. Saúde Debate. 2010;24(54):66-74.

28. Cericato GO, Garbin D, Fernandes APS. A inserção do cirurgião-dentista no PSF: uma revisão crítica sobre as ações e os métodos de avaliação das Equipes de Saúde Bucal. RFO. 2007;12(3):18-23.

29. Vilarinho, SMM, Mendes, RF, Prado Júnior, RR. Perfil dos cirurgiões-dentistas integrantes do Programa Saúde da Família em Teresina (PI). Rev Odonto Cienc. 2007;22(55):48-54.

\section{CONFLICT OF INTEREST}

The authors declare no conflicts of interest.

\section{CORRESPONDING AUTHOR}

Mirella Gonçalves Caldeira Padula

Rua Edmundo Simões de Mello, 36, CECAP Aeroporto, 17514-430 Marília - SP, Brasil

e-mail: mirellapadula@gmail.com 